\title{
Yevhen Laniuk
}

Ivan Franko National University of Lviv

\section{Technocracy as a challenge to political freedom in the digital age}

The government of the former Prime-Minister of Ukraine Olexiy Honcharuk named itself "the government of technocrats". This shows that the concept of technocracy becomes attractive in Ukraine. Technocracy is the form of government, which attempts to distance itself from political representation or affiliation with a particular ideology. Technocrats derive their legitimacy from their skills and expertise, and focus primarily on problem-solving and optimizing the society's useful functions.

Technocracy has always been a promising political concept. The Republic by Plato can be regarded as the first attempt to substantiate a technocratic society, in which power proceeds from the expertise of its dominant elite. Technocracy was very appealing in the industrial age, when scientific management of factories inspired the idea that society at large could be governed by similar methods. Today, digital technologies and Big Data reinvigorate the technocratic project.

In this article it has been shown that technocracy, if taken too far, can be antithetical to liberal democracy and its core value - political freedom. Technocratic society resembles a corporation run by the board of directors rather than a republic of citizens. We have pointed out the factors, which make it appealing in the modern world. We then have analyzed the ideas of Howard Scott, the founder of the movement Technocracy Inc., who advocated this political model in the industrial age, and Parag Khanna, who has made similar claims about the benefits of technocracy in the digital age. It has been proven that both these thinkers share the same illiberal mindset including the common faith in the applicability of scientific methods of social management without regard for popular votes and opinions, admiration of autocratic powers of the day, and disregard for democratic procedures, which they see as hurdles on the path toward economic well-being and political domination. Finally, we asked the question: if the challenge to political freedom in Ukraine proceeds from technocracy, will it be defended in the same way as during the three Ukrainian Maidans (1990, 2004, 2014)? We deliberately leave this question unanswered, hoping that the answer will be investigated in future publications.

Keywords: technocracy, political freedom, democracy, digital age, Howard Scott, Parag Khanna, Ukraine

\section{ЄВген Ланюк}

\section{Львівський наџіональний університету імені Івана Франка}

\section{Технократія як виклик політичній свободі у цифрову епоху}

Уряд колишнього прем'єр-міністра України Олексія Гончарука назвав себе «урядом технократів». Це вказує на те, що концепція технократії стає дедалі привабливішою в Україні. Технократія - це тип правління, що намагається дистанціюватися від політичного представництва чи приналежності до певної ідеології. Легітимність технократів обумовлена, передусім, їхніми навичками, а свою увагу вони зосереджують, передусім, на вирішенні проблем та оптимізації корисних функцій суспільства.

Технократія була привабливою у різні історичні епохи. «Державу» Платона можна вважати першою спробою обгрунтувати технократичне суспільство, в якому влада грунтується на навиках та знаннях його керівної верстви. Також, технократію вважали напрочуд перспективною у промислову епоху, коли науковий менеджмент підприємств надихнув ідею, що суспільством загалом можна керувати схожими методами. Сьогодні технократія отримує новий стимул від стрімкого розвитку комп'ютерних технологій і «великих даних».

У статті стверджується, що технократичний проект може суперечити ліберальній демократії та іiі ключовій цінності - політичній свободі. Технократичне суспільство нагадує радше корпорацію, якою керує рада директорів, аніж республіку громадян. Було вказано на фактори, які лежать в основі привабливості технократії у сучасному світі. Також, було проаналізовано ідеї Говарда Скотта, засновника руху Technocracy Inc. у 1930-х pp. у США, який відстоював технократію у промислову епоху, та Парага Ханни, який обгрунтовує іiі переваги над демократією у цифрову епоху. Обидва автори мають чітко виражену антиліберальну позицію, яка включає переконання, що суспільством потрібно керувати на основі «наукових методів», а не демократичних голосів; захоплення авторитарними державами відповідних історичних епох, 
а також трактування демократичних норм і процедур як перепон на шляху до економічного процвітання та політичної могутності. Наприкінці було поставлено питання: якщо основний виклик для політичної свободи в Україні походитиме від технократії, чи захищатимуть їі так само, як це відбувалося під час трьох українських Майданів (1990, 2004, 2014 рр.)? Ми залишаємо це запитання без відповіді, сподіваючись, що воно буде досліджено у майбутніх публікаціях.

Ключові слова: птехнократія, політична свобода, демократія, циифрова епоха, Говард Скотт, Параг Ханна, Украӥна

\section{Introduction.}

7 he government of the former Prime-Minister of Ukraine Olexiy 1 Honcharuk named itself "the government of technocrats." (RPR, 2019) This shows that the concept of technocracy becomes ever more attractive for Ukraine. Technocrats distance themselves from political ideologies, representation of particular groups of voters, and affiliation with traditions and values of society. Instead, they attempt to act as managers focusing primarily on problem-solving and optimizing the society's useful output. Their techniques are purely instrumental: more GDP, less crime and poverty, better infrastructure, etc., and their political credo is not liberalism, conservatism, socialism or nationalism, but, mostly, pragmatism. Technocratic politicians, thus, resemble rather corporate managers than elected representatives of the people.

Technocracy becomes especially appealing in times of crisis. In an unstable society, plagued by conflicts and tug-wars between different sets of values (national, ideological or religious), there is a temptation to bring to power apolitical administrators, who will dissociate themselves from thorny political issues and will act as neutral managers addressing only those problems, which can be objectively measured and are usually universally approved (the growth of economy, fighting corruption, building a better infrastructure, etc.). Therefore, it was no coincidence that the government of Olexiy Honcharuk presented itself as technocratic precisely after the divisive presidential elections in Ukraine in 2019. Even the President Volodymyr Zelensky himself referred to this rhetoric when he said, in his 2020 New Year address, that "the name of the street doesn't matter because it is lit and paved." (UNIAN, 2020)

Considering the high level of support of this speech (Rating, 2020), as well as the fact that over $60 \%$ of Ukrainians uphold the argument that "the country needs a "strong hand' rather than the talks about democracy" (Protsenko, 2019), technocracy might become a viable political option in our country.

In this article, we made an attempt to show that technocracy, if taken too far, is a dangerous position, which can threaten the core political value - freedom. The thinking behind this model (emphasis on pragmaticism, rationality, welfare and useful output) has already inspired a series of illiberal political projects, both imaginary (e. g., Thomas More's Utopia) and real-life (totalitarian and autocratic regimes of the 20th and 21 st centuries).

In the modern world technocracy is again very attractive. Several factors have converged to make it so. First of all, the rise of Big Data and sophisticated computer technologies. The digital age fosters the idea that for the first time in history, thanks to new technologies, it is possible to solve every human problem virtually and to create a "better" society. Second, democracy nowadays faces hardships. Not only has a tide of populism recently swept over Europe and North America, but also the global pandemic has shown that it could be surprisingly easy for people to give up their liberties and yield to instrumental regimentation of their lives. Third, the rapid economic growth in the East (especially, in China and Singapore) versus stagnation in the West makes the East Asian autocratic political model, based on technocratic expertise rather than democratic legitimacy, an appealing ideal for the rest of the world. In the past, Western countries could attribute their successful economies to their democratic politics. Today, against the backdrop of China, they can no longer make such claims.

The aim of research is to give weight to the claim that excessive technocracy can be detrimental to political freedom. In this article, we made an attempt to show why it might be the case and how it can occur in the digital age. In today's rapidly changing world, Ukraine should find an optimal model of its political development. Since the first persons 
of our country have declared their commitment to technocracy, we hope that this article can contribute to the awareness about the potential dangers of this political model.

Analysis of publications. The perils of unrestrained technocratic government have already been covered in a number of publications, including: (Reiser \& Hebenstreit, 2020), (Esmark, 2020), (Easterly, 2019), (Berman, 2018), (Bickerton \& Accetti, 2015), (Habermas, 2015), (Bucchi, 2009), (Centeno, 1993). Among older publications, which still contain valuable insights into the topic, is: (Temple, 1944). An eulogy to technocracy as a viable alternative to democracy in the digital age can be found in: (Khanna, 2017). Consideration of illiberal political practices assisted by digital technologies can be found in: (Harari, 2018), (Gray, 2019). The discussion about the political value of freedom and its connection with liberal democracy can be found in: (Bova, 1997), (Beetham, 2004), (Laniuk, 2019).

\section{Discussion.}

The term "technocracy" derives from the Greek words " $\tau \dot{\varepsilon} \chi v \eta "$ (tekhne meaning skill)

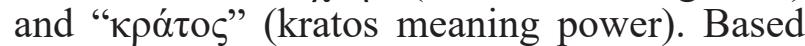
on the ambiguity of the Greek work tekhne, it is possible to interpret it in two ways: 1 . as the power of the scientific and technical elite; 2 . as the power of technologies, which the British economist Arthur W. Brian defines as "a means to fulfill a human purpose." (Brian, 2011, p. 28). Miguel Angel Centeno characterizes technocracy as "the administrative and political domination of a society by a state elite and allied institutions that seek to impose a single, exclusive policy paradigm based on the application of instrumentally rational techniques" (Centeno, 1993). This definition highlights the unity between technologies and power whereby human society is approached as a kind of "raw material" for the implementation of rationally defined policies of its dominant elite.

In this article, the connection between freedom and democracy will not be covered, because we have already done it in our previous publication (Laniuk, 2019). For this analysis it would be enough to say that we regard liberal democracy as institutionalized freedom. According to Isaiah Berlin, political freedom has two dimensions, namely, negative and positive one (Berlin, 1969, p. 121). Liberal democracy enables both these dimensions. It is the guardian of negative freedom (via its courts and law-enforcement agencies) and the embodiment of positive freedom (through elections and referendums representing the will of the people). This allows interpreting freedom as an "Alpha and Omega" of liberal democracy. This does not deny, of course, that liberal democracies should not strive for effective governance, capable leadership or powerful military, however, these goals should be regarded not as independent ends, but only as a means of protecting and increasing their citizens' freedom.

On the other hand, the "Alpha and Omega" of technocracy is not freedom, but the pragmatic optimization of society's measurable functions (more GDP, less crime, etc.). If democratic procedures and human rights stay in the way of these functions, a consistent technocrat will brush them aside, as it happens, for example, in China or Singapore, where the society's useful output and smooth workings of its institutions are more praised than the rights and freedoms of its citizens. According to Centeno, technocracy has several characteristics, which constitute it as a specific political form. The technocrats are usually appointed rather than elected. They focus primarily on problem-solving than on representation. Usually, they have received a technical education and, because of this fact, have a "shared faith in the applicability and superiority of technical methodologies and paradigms," which is accompanied by the "assumption that rationality is beyond dogmatism, and that scientific analysis knows no ideology." (Centeno, 1993) Their commitment to scientific rationality determines their implicit and often explicit, rejection of politics as "inefficient and possibly corruptive." (Centeno, 1993)

Technocracy can be seen as an antagonistic pole of democracy. Democracy emphasizes the sovereignty of people; technocracy believes in the sovereignty of expertise. Democracy first represents and then rules, technocracy favors ruling without representation. Democracy is based on the premise that society consists of different groups and interests; technocracy treats it as an indiscriminate whole. Technocracy is not only opposed to democracy, but, according to Centeno, is also similar to theocratic regimes of the ancient world: "In imposing the domination 
by an instrumental rationale and scientific method, technocracies are similar to theocratic regimes or states that have explicit, dominant political ideologies. In all these cases, legitimacy comes not from the barrel of a gun or from the ballot box, but from adherence to the dictates of a 'book.' Whether that document contains the word of God, a theory of history, or the econometric functions that describe equilibria, those best able to interpret its message and implement its laws cannot take opposition or popular participation into account." (Centeno, 1993)

Technocracy is opposed not only to democracy, but also to freedom, insofar as freedom is its supreme value. The most straightforward way to view it in this light is to point out the common features of technocracy and totalitarianism. The application of "instrumentally rational techniques," which must produce "measurable results," according to Centeno, is a distinctive feature of technocracy, but historically it has been a hallmark of totalitarianism. Aldous Huxley wrote his famous dystopia Brave New World (1932) under the impression from the rule of scientists and engineers who were summoned by Franklin D. Roosevelt into his administration after the start of the Great Depression. Though Huxley's novel is a fiction, he nevertheless captured the technocratic dream: a society, which is ruled "scientifically" and whose every aspect is carefully analyzed, planned and controlled by the experts.

The old adage says: "The road to hell is paved with good intentions." The technocratic pursuit of efficiency, convenience and measurable outputs, ifleft unchecked, can lead to a tyrannical prison-world. The Utopian socialists (Henri de Saint-Simon, Charles Fourier, Étienne Cabet and Robert Owen) described rationally planned and scientifically governed societies. These early speculations inspired Karl Marx and Vladimir Lenin to conceive not a fictional, but a real totalitarian world, whose distinctive feature was a large-scale technocratic experimentation with nature and society.

At one point, technocracy also had totalitarian overtones in the United States. Scathing criticism of the views of Howard Scott, the founder of the movement Technocracy Inc., uncovers the totalitarian features of technocracy. In the 1930s, Scott proposed to replace American politicians with scientists and engineers and founded a social movement to assist this goal. We would like to cite some of Scott's arguments along with the responses of his critic Paul Temple, because they bear a striking resemblance to the rhetoric of today's champions of technocracy, which we will analyze later in this article (unfortunately, no works of Howard Scott are directly available in Ukraine, therefore, we quote his arguments as cited by his critique Paul Temple).

Scott believed that it was "a grandiose nonsense" that "the collective multiplication of human opinion was the nearest possible approach to divine omniscience in the solution of all political problems" (as cited in Temple, 1944). "Political liberty," he believed, "is a dead issue today" (as cited in Temple 1944). Paul Temple commented in 1944 that these passages sounded as "translations from contemporary German:" "The Nazis," he wrote, "based their anti-democratic propaganda on a mystic 'Führer-prinzip,' while Scott bases his on 'science.' No one ever took a vote on the law of gravitation, reasons Scott like a precocious schoolboy. Why should we rely on votes to tell us how to engineer society?" (Temple, 1944)

The sole rationale of technocracy, according to Scott, is that it was efficient. "Technocrats," he explained, "are not filled with any love for humanity or influenced by any ethical idea but are primarily concerned with function" (as cited in Temple, 1944). This serves as a "sufficient reason" to adopt technocracy even despite the wishes of the people who would have to live under it.

In 1939, Scott's movement adopted the attributes, which were very similar to the "black shirts" of Mussolini or Hitler's "Sturmabteilung." Its members wore uniforms and called Scott "the Chief" (English translation of Der Führer). In his pamphlet Pax Americana (1939), Scott curtsied to Adolf Hitler writing that "Technocracy would like to point out that regardless of how we regard Herr Hitler and the Nazi regime of Germany, they are the embodiment of the expression of the will of the German people" (as cited in Temple, 1944). According to Paul Temple, he said the same for Stalin (then Hitler's partner), praising the "increased efficiency brought about by their regimes" (as cited in Temple, 1944).

This brief analysis shows that technocracy 
can be antithetical to freedom. When the society's productive output and frictionless workings of its institutions displace freedom as the main rationale of its existence, such a society downgrades to a sort of "animal farm," which is run "scientifically". People will be unable to control the policies affecting them and the society will resemble rather a corporation run by the board of directors than a republic of citizens.

Despite its illiberal overtones and past failures, technocracy is a recurrent lure. It was attractive in different historical epochs (ancient, as well as modern), but mostly in transitional historicalperiods, when new political, economic and social practices challenged the established values. One example was the Renaissance. When the medieval society was collapsing under the joint force of capitalist economy and scientific rationality, many thinkers (e.g., Thomas More, Tommaso Campanella, Francis Bacon, etc.) devised ideal communities ruled by dispassionate administrators for the benefit of all their members. Another episode was the industrial age when the efficient and highly rational management of labor at factories inspired the idea that society at large could be governed by the same methods.

Today, new technologies also create similar temptations and feats. Big Data and cutting-edge computers have accelerated the economy and awakened the old dream about infinite progress. Therefore, there are again voices asking whether it would not be better to entrust the society to "experts" rather than voters. At the same time, the competition with such countries, as China, that introduce technocratic methods of ruling without much regard for privacy and human rights, prompts their western counterparts to follow the same road. Unsurprisingly, there are already champions of this political ideal. Let us quote one of them.

Like Howard Scott in the 1930s, the American author Parag Khanna in his book Technocracy in America: Rise of the InfoState (2017) repeatedly argues that democracy is passing out and does nothing good except breeding populism and bringing to power mostly incompetent politicians. According to him, "everyday people don't measure their lives by how democratic their state is, but whether they feel safe in their cities, can afford their homes, have stability in their work, have a plan for growing old and can remain connected to friends and family" (Khanna, 2017, p. 14). A good political system is the one which "delivers:" "The input of democracy," he argues, "can never compensate for the output legitimacy of delivering the basics" (Khanna, 2017, p. 20).

In his book he makes a forthright claim that human rights, the rule of law, the people's sovereignty and other pillars of democracy can be sacrificed for the sake of economic output and material well-being. "We are coming to appreciate," writes Khanna, "that the difference between successful and failing countries is not rich vs. poor, left vs. right or democratic vs. authoritarian, but whether they have the capacity to meet their citizens' basic needs" (Khanna, 2017, p. 15).

In the same way as Howard Scott praised "increasing efficiency" brought by the regimes of Hitler and Stalin, Parag Khanna assigns a large portion of his book to the veneration of successfulnon-democratic countries, especially Singapore and China, which he contrasts with their less performing democratic counterparts, such as India. "China's spectacular rise versus that of democracies," he writes, "has shown the World that it is better to have a system focused on delivery without democracy than a system that's too democratic at the expense of delivery" (Khanna, 2017, p. 20). However, he totally misses the price these countries had to pay for their high-performing economies. For example, his accolade to the Communist dictator Deng Xiaoping whose "accrued experiments resulted in China's economic miracle" (Khanna, 2017, p. 26) totally ignores his responsibility for the massacre of the democratic opposition in the Tiananmen Square in 1989.

As we see, Parag Khanna's arguments about the benefits of technocracy echo the statements of Howard Scott formulated almost ninety years ago. What is different, though, is his emphasis on cutting-edge digital technologies - Big Data and supercomputers - as a means to arrive in the society of the future. He calls the type of state he envisages an "Info-State" and advocates the extensive use of digital technologies for social planning. There will be no elections or referendums in the "Info-State," because its policies will be based directly on data. In 
totalitarian political projects, starting from The Republic by Plato, power did proceed not from the consent of the people, but from some pre-political, metaphysical "truth" (it could be either divine justice or dialectical materialism), contemplated by the supreme authority (philosophers-kings or the Communist Party). In Khanna's "Info-State," it is Big Data, which again justifies the old idea about the "reign of truth."

In a nutshell, Parag Khanna's Technocracy in America: Rise of the Info-State promises a sterile and flawless unfree world, in which the unelected and unaccountable "inner party" will govern the society with the help of a larger "outer party" of civil "apparatchiks" and Big Data technologies while treating it as a private enterprise. The citizens of the Info-State will no longer be "we, the people." Instead, they will be reduced to a consultation body probed via ubiquitous surveillance.

At the end it is appropriate to ask a question: Can Parag Khanna's Info-State be a model for Ukraine? The long experience of living under autocraticand totalitarianregimeshascontributed to our population's generally low commitment to the value of political freedom. Another part of this historical legacy is the consumerist and materialistic mentality. Therefore, if the "InfoState" is built in our country, we believe that many people will not object to it. At the same time, in its recent history Ukraine has undergone three political revolutions - the Revolution on Granite (1990), the Orange Revolution (2004) and the EuroMaidan revolution (2014). In all these events, their participants fought for the ideals of freedom and democracy against sluggish, corrupt and politically bankrupt elites. However, imagine a different scenario, in which the enemies of political freedom are not retrograde, dishonest, luxury-loving and criminal politicians, but skilled, Westerneducated, white-collar and performanceoriented technocrats. Will we go to the Maidan Square to protest them and fight for freedom? Let us leave this question unanswered.

\section{Conclusions.}

In this article the concept of technocracy has been outlined and its features have been highlighted. It has been emphasized that this political form is pre-occupied primarily with the optimization of society's useful output, which it values above democratic procedures meant to safeguard political freedom. It has been maintained that technocracy becomes especially attractive in transitional historical periods when humankind invents a new rationalistic toolkit laden with great transforming power and expectations. In the modern world three circumstances make technocracy especially appealing. First of all, the rise of Big Data digital technologies. They foster the idea that human society can be ruled based on data rather than democratic votes, and, thus, revive the ancient idea of "the reign of truth," which goes back to Plato's The Republic. The second factor is the hardships that liberal democracy undergoes in the modern world. The hardships include the tide of populist movements and politicians that swept across Europe and North America in recent years, and the global pandemic, which demonstrates that it could be surprisingly easy for people to give away their freedom and yield to technocratic regimentation of their lives. The third factor is the competition with such countries as China, which make the useful output of society (both economic and military) a cornerstone of their policies, while having little regard for human rights and democratic procedures. The struggle with such countries urges some of their practices, including technocracy, also in the West. The ideas of Howard Scott, who advocated technocracy in the industrial period, and Parag Khanna, who is its champion in the digital age, have been discussed and the illiberal nature of both these authors' mindset has been shown. Both Scott and Khanna admired the autocratic powers of the day, had a shared faith in the application of rationalistic and scientific methods of social management, disregarded democratic procedures, which they saw as hurdles on the way of economic well-being and political power, and advocated their technocratic political models as ultra-modern and meeting the Zeitgeist of their respective ages. Finally, a statement has been made that, because of several historical reasons, technocracy potentially can be viewed as a viable political option in Ukraine and the question has been asked: Will political freedom be defended in Ukraine if its enemies are skilled and performance-oriented technocrats? We deliberately left this question unanswered. Perhaps it can be addressed in future publications. 


\section{REFERENCES}

Bucchi, M. (2009). Beyond technocracy: Science, politics, and citizens. Springer Science \& Business Media.

Beetham, D. (2005). Freedom as the Foundation. Journal of Democracy, 15(4), 61-75. https://doi.org/10.1353/ jod.2004.0057.

Berlin, I. (1969). Four essays of liberty. Oxford University Press.

Berman, S. (2018). Against the Technocrats. Dissent Magazine. https://www.dissentmagazine.org/article/againsttechnocrats-liberal-democracy-history.

Bickerton, C., \& Accetti, C. I. (2015). Populism and Technocracy: Opposites or Complements? Critical Review of International Social and Political Philosophy, 20(2), 186-206. https://doi.org/10.1080/13698230.2014.995504.

Bova, R. (1997). Democracy and Liberty: The Cultural Connection. Journal of Democracy, 8(1), 112-126. https:// doi.org/10.1353/jod.1997.0016.

Brian, A. (2011). The Nature of Technology: What It Is and How It Evolves. Free Press.

Centeno, M. A. (1993). The New Leviathan: The Dynamics and Limits of Technocracy. Theory and Society, 22(3), 307-335. https://doi.org/10.1007/BF00993531

Easterly, W. (2016, December). Democracy Is Dying as Technocrats Watch. Foreign Policy. https://foreignpolicy. com/2016/12/23/democracy-is-dying-as-technocrats-watch/.

Esmark, A. (2020). The New Technocracy. Policy Press.

Gray, J. (2019, February). The New Tech Totalitarianism. New Statesman America. https://www.newstatesman. com/culture/books/2019/02/new-tech-totalitarianism.

Habermas, J. (2015). The Lure of Technocracy. John Wiley \& Sons.

Harari, Y. N. (2018, September). The Myth of Freedom. The Guardian. https://www.theguardian.com/books/2018/ sep/14/yuval-noah-harari-the-new-threat-to-liberal-democracy.

Khanna, P. (2017). Technocracy in America: Rise of the Info-state. CreateSpace.

Laniuk, Y. (2019). Freedom as a Foundation of Liberal Democracy: A Normative Perspective. Visnuk of the Lviv University. Series Philosophical Science, 23, 35-46. https://doi.org/10.30970/2078-6999-2019-23-5

Protsenko, V. (2019, February 23). The "Strong Hand" Curse: Why Ukrainians Do Not Like Capitalism. Vox Ukraine. https:/voxukraine.org/en/the-strong-hand-curse-why-ukrainians-do-not-like-capitalism/

Rating Group. (2020, February). SOCIO-POLITICAL MOODS OF POPULATION (22-26 JANUARY, 2020).http://ratinggroup.ua/en/research/ukraine/obschestvenno-politicheskie_nastroeniya_naseleniya_22-26_ yanvarya_2020_goda.html

Reiser, M., \& Hebenstreit, J. (2020). Populism versus technocracy? Populist responses to the technocratic nature of the EU. Politics and Governance, 8(4), 568-579.

Reanimation Package of Reforms. (2019, November). Honcharuk government: the first victories and failures of young reformers. RPR. https://rpr.org.ua/en/news/honcharuk-government-the-first-victories-and-failures-of-youngreformers/

Temple, P. (1944). A Totalitarian Fantasy -Technocracy, Fascism, and the War. New International, 10(4), 118 121. https://www.marxists.org/archive/draper/1944/04/technocracy.htm

Zelensky New Year address: Everyone should answer the question: who am I? (2020, January 1). UNIAN. https:// www.unian.info/society/10816211-zelensky-s-new-year-address-everyone-should-answer-the-question-who-am-i.html

\section{Laniuk Yevhen}

Ph.D., https://orcid.org/0000-0003-0171-9802, yevhen.lanyuk@lnu.edu.ua 